\title{
Possible adjustments of suckler herd management to extensive situations
}

\author{
Pascal D'hour ${ }^{\mathrm{a} *}$, Ricardo Revilla ${ }^{\mathrm{b}}$, Iain A. Wright ${ }^{\mathfrak{c}}$ \\ a LAHM-Inra, Centre de Clermont-Ferrand/Theix, 63122 Saint-Genès Champanelle, France \\ ${ }^{\text {b }}$ S.I.A-D.G.A., Unidad de Teccnologia Animale, Apdo 727, 5080 Zaragoza, Spain \\ ${ }^{c}$ Macaulay Land Use Research Institute, Craigiebuckler, Aberdeen, AB 15 8QH, UK
}

(Received 29 May 1998; accepted 10 July 1998)

\begin{abstract}
Suckler herd management, based on the maximal use of grazed or harvested grass, is already extensive in most situations. An appropriate change of calving date fits herd management to seasonal variations in food supply. When grass production is sufficient, spring calving increases the proportion of grazed grass in the annual feed and reduces the need for harvested forages. If good forages are available for only a short time, the lactation period can also be shortened, which splits up the requirements of the dam and the calf. On the other hand, when grass production is low and/or grassland of poor quality, cows can calve in early winter and be dried off when turned out at pasture. Their reproductive performance is thus maintained at an acceptable level. Suckler herds can contribute to the control and the maintenance of vegetation, for example by lengthening the grazing season far beyond the period of active vegetation growth. An increase in stocking rate at certain key periods can be used to control undesirable species efficiently. The genotypes adapted to extensive management conditions are characterized by their good maternal abilities, their relatively high intake capacity on roughages and low quality grass, and their ability to mobilize then recover body reserves. CElsevier / Inra
\end{abstract}

\section{suckler herd / management / extensification / grazing / breed}

Résumé - Adaptations possibles de la conduite du troupeau allaitant aux situations extensives. La conduite de la plupart des troupeaux de vaches allaitantes, basée sur l'utilisation de l'herbe pâturée ou conservée, est déjà extensive. Modifier la date de vêlage permet d'adapter la conduite du troupeau aux ressources fourragères. Lorsque la production d'herbe est suffisante pour satisfaire les besoins alimentaires du couple vache-veau, faire vêler les vaches au début de la période de végétation accroit la participation de l'herbe pâturée à l'alimentation du troupeau et limite ainsi les besoins en fourrages récoltés. Inversement si la production des prairies est insuffisante, les vaches peuvent vêler pendant l'hivernage et être taries au pâturage. Leurs performances de reproduction sont alors préservées. Dans ces conditions plus difficiles, la durée de lactation peut être raccourcie, ce qui dissocie les

* Correspondence and reprints

Tel.: (33) 04736240 86; fax: (33) 04736241 18; e-mail: dhour@clermont.inra.fr 
besoins de la mère et du jeune. Les troupeaux de bovins allaitants peuvent contribuer à l'entretien des espaces herbagers avec des ajustements de la conduite du pâturage, par exemple en allongeant la durée de pâturage au-delà de la période de végétation active. Une augmentation du chargement à certaines période clés limite l'extension de végétations indésirables. Les races adaptées aux conditions extensives se caractérisent par leurs bonnes aptitudes maternelles et leur aptitude à mobiliser puis reconstituer leurs réserves corporelles et à ingérer des fourrages grossiers. (O) Elsevier / Inra

\section{troupeau allaitant / conduite / extensification / pâturage / race}

\section{INTRODUCTION}

Suckler cows contribute to the maintenance of rural areas, especially through the maintenance of grasslands, in addition to having a productive function. Livestock farmers however must be able to make their living from their herds, and in Europe, since the CAP reform of 1992, the provision of subsidies (extensive farming premium, agroenvironmental measures including the grass premium) has acknowledged the importance of suckler herds in the rural economy and rural development.

In $1995,68 \%$ of the suckler cows in the European Union were located in France, Britain and Spain [2]. As the productivity of suckler herds is modest in comparison to other agriculture sectors, they are mainly confined to less favoured areas. In France, $57 \%$ of suckler herds are found in less favoured lowland areas and upland regions; the northern and western edges of the Massif Central, the Massif Central and the edge of the Pyrenees. In Britain, $72 \%$ of suckler cows are found in the less favoured areas. In Spain, suckler herds are found in humid and hilly or mountainous regions ( $40 \%$ in Galicia, North-West and Pyrenees), but also in dry regions $(60 \%$ in Andalusia and Extremadura). Herd management must therefore be adapted to the environmental constraints of these regions. In these traditional regions production systems are extensive, based on the maximal use of grazed or conserved grass, because of the agroclimatic constraints and limited use of fertilizers. In French and British grassland regions, the stocking rate over the forage area in most farms with suckler herds ranges from 0.9 to 1.4 L.U.ha ${ }^{-1}$ ([24]; Lowman B.G., personal communication), and remains below that of dairy farms. The size of the herds and area of pasture per herd is continually increasing, while costs of consumables and labor are falling [24]. In the more arid regions, especially Andalusia and Extremadura in Spain, the management system resembles ranching with few or no buildings, outdoor wintering, grazing all year round with a very low stocking rate $\left(0.2\right.$ to $\left.0.4 \mathrm{LU} \cdot \mathrm{ha}^{-1}\right)[16]$.

In almost all these regions, the main food source is permanent pasture of varying degrees of productivity, either grazed or conserved. The cattle must adapt to seasonal and annual variations in the quantity and quality of the forage resources. The herd management therefore relies on the adaptability of the cattle to these alternating periods of abundance and shortage of feed [29], while taking care not to impair the reproductive performance of the cows, which ultimately determines their productivity.

Possible adjustments to the management of suckler herds concern the choice of calving season and duration of suckling. In this paper the current management of suckler herds in marginal grassland areas will firstly be discussed. Secondly, the possibilities of using suckler cows as a means of controlling vegetation and the consequences for animal performance will be described. The choice of genotypes best adapted to these conditions and/or stock-raising methods will also be discussed. 


\section{ADJUSTING MANAGEMENT TO FORAGE RESOURCES}

One of the first adjustments that can be made to management of suckler herd consists of delaying the age at which production starts. The youngest cows are the most sensitive to variations in food supply. In fact, the age at first calving is often delayed in extensive systems compared with intensive systems. Bringing forward the age of first calving requires the heifers to be provided with a high level of feeding, but it is often these heifers that utilize the poorest forage and the roughest pastures of the farms. Slower-maturing continental cattle breeds commonly calve first at 3 years old, because of both a later puberty [14] and the risks associated with insufficient development at calving (dystocia, subsequent reduction of fertility). The crossbred genotypes used in Britain mature earlier [29], and the age at first calving is between 24 and 30 months. This is facilitated by the fact that replacement heifers from dairy herds, born in autumn or spring, are available on the market.

Adjustment to management may also consist of adjusting the periods of high physiological demand for nutrients (particularly lactation) to coincide with periods of abundant forage availability i.e., with the periods of grass growth. A highly sensitive period is mating, which should occur at a time of plentiful forage supply. Thus the traditional timing of calving has been at the end of winter with the weaning of calves in the autumn. When the grazed or conserved forage resources are readily available throughout the year, and the winter is short, the performance of herds depends little on calving time [3]. In contrast, in other situations, the nutritional requirements of the cows have to match the variations in forage availability to ensure an acceptable level of herd performance. This is probably why the time of calving on upland farms is somewhat delayed compared with lowland farms rearing the same breeds: for example 15 days in Salers area and 33 days in Limousin area $[6,7]$. The choice of weaning age can contribute to fitting variations in demand to variations in forage supply, and also dissociate the demand of the cow and calf and so adjust the forage supply for each separately.

The nutritional management of the cows can also allow for their ability to mobilize body reserves to reduce their requirements for winter forage [29]. Thus feeding recommendations usually advocate underfeeding cows in winter if the state of their body reserves at the start of winter is adequate [1]. At pasture, when grass production is insufficient, giving concentrate supplementation for calves and conserved forage for the dams is traditional.

The proportion of total energy requirements met by grazing depends to a large extent on calving season and the duration of lactation. The requirements of the cow and calf have been calculated for different calving seasons and weaning times, assuming an upland area $(1100 \mathrm{~m}$ above sea level), with abundant pasture, a winter period of about 6 months and reasonable underfeeding during winter (table I). Autumn calving is costly in terms of conserved forage, which has to meet half the annual energy needs of cow and calf. It often entails housing the cows and their calves in advance of the cold winter weather, thereby lengthening the indoor winter feeding period. The level of feeding of housed cows in winter has to be high during the period of reproduction, and the calves have to receive a supplementary, concentrate-rich feed. On the other hand, autumn calving allows the calves to be born outdoors, which reduces mortality, provided the climatic conditions are favorable. Finally autumn calving may be the most suitable for regions with short winters and dry summers, the cows being dry over summer and so having reduced feed requirements. Autumn calving may also allow weaned calves to be sold at a time of year when the supply is low and prices high. 
Traditionally, in French upland areas cows calve in mid-winter or early spring. In this system the proportion of the total diet supplied by conserved forage is lower than that in the autumn calving system, given the reduced duration of suckling indoors, and since more severe winter underfeeding can be tolerated because mating occurs during grazing. Grazed grass then accounts for $67 \%$ of the annual energy needs (table I). However, the calves have to be weaned before the following winter, often at a younger age and lighter live weight than autumn-born calves.

In a study in Scotland (Wright et al., unpublished data) Hereford $\times$ Friesian cows calving in autumn or spring were fed in winter such that they were in the same body condition at turn-out to pasture in spring. The winter feed requirements of the autumncalving cows was $25 \%$ higher than that of the spring-calving cows. However, because the autumn-born calves were older at weaning they were also heavier (table $I$ ).

In the case of late-spring calving (late May-early June) associated with autumn weaning, both lactation and reproduction occur during grazing periods. The cows are dry during the whole winter and their feed can be limited to maintenance levels or below if they are in good body condition at start of wintering. The annual requirements of cow and suckled calf are reduced to 2 600-2 700 UFL (feed unit for lactation, $1 \mathrm{UFL}=7.11 \mathrm{MJ}$ of net energy for lactation), of which $73 \%$ could be supplied by grazing (table $I$ ). The short lactation and resulting reduction of total annual energy requirements compared with calving in February makes May-June calving suitable for systems with limited forage resources. However, the calf, weaned at 5 months, has to be given a higher energy feed thereafter, for example $1 / 3$ concentrate and $2 / 3$ good quality hay $(\mathrm{OMD}>0.6)$ to obtain a high daily live weight gain. In these conditions, the energy cost of feeding the weaned calf represents about 400 UFL from 5 to 9 months of age [11].

In a comparison of different calving seasons in France, the number of calves produced and the growth rate of the calves were similar [27]. The pregnancy rates of the cows calving in autumn or spring ( 87 and $89 \%$ ), were lower than those of cows calving in mid-winter $(93 \%)$ because the mating period was limited to 2 months in autumnand spring-calving cows compared to 4 months for winter-calving cows (table I). Calf mortality was lower when calving was outdoors, and so the overall number of calves produced was similar.

Table I. Calculated energy requirements and observed performance of a Salers suckler herd with different calving dates and lactation lengths in Massif Central, France

\begin{tabular}{lcrr}
\hline Calving date & 15th September & 15th February & 1st June \\
\hline Lactation length (days) & 273 & 245 & 136 \\
Length of wintering (days) & 191 & 181 & 171 \\
Total energy requirement* per cow and calf (UFL) & 3830 & 3559 & 2654 \\
Calf energy requirement (UFL) & 596 & 457 & 93 \\
Requirements covered by grazed grass (\%) & 52 & 67 & 73 \\
Pregnancy rate** (\%) & 87 & 93 & 89 \\
Calf mortality (\%) & $4-5$ & $6-8$ & $3-4$ \\
Calf weaning live weight (kg) & 300 & 284 & 199 \\
\hline
\end{tabular}

$* 1 \mathrm{UFL}=7.11 \mathrm{MJ}$ of net energy for lactation.

** Mating period lasted 2 months in autumn and spring-calving cows and 4 months in winter calving cows. Calculated from Agabriel and Petit [1] and adapted from Petit et al. [27]. 
Table II. Performance of autumn- and spring-calving Hereford $\times$ Friesian suckler cows.

\begin{tabular}{lcc}
\hline Season of calving & March-April & 15 August-15 October \\
\hline Cows & & 2.4 \\
$\quad$ Body condition score in spring & +0.5 & +0.6 \\
$\quad$ Change in body condition at pasture & & 9.5 \\
Calves & 6.0 & 347 \\
$\quad$ Age at weaning (months) & 303 & 9057 \\
$\quad$ Live weight at weaning (kg) & 7210 & \\
Winter feed requirements per cow (MJ ME/day) & & \\
\hline
\end{tabular}

Wright et al. (unpublished data).

When the production of spring and summer pasture is insufficient to provide lactating cows with an adequate level of nutrition, autumn calving associated with weaning at 5 months enables the reproductive performance of the cows to be maintained (table III). Thus in the Spanish Pyrenees, the cows graze rough pastures in spring and sometimes use rather poor mountain pastures in summer. When the grazing cows are dry their live weight gain is $55 \mathrm{~kg}$ [9]. At the following calving their body condition is sufficient to tolerate subsequent winter underfeeding without impairment of reproductive performance. Conversely, cows calving in mid-March and grazing poor pasture from mid-June, have insufficient live weight gain $(13.5 \mathrm{~kg})$ and recovery of body reserves (table III). During winter, these cows must be fed above their maintenance requirements for their body condition score at calving to reach 2.5 so as not to jeopardize their future reproductive performance. From these findings, Casasus [8] calculated that the winter energy supply necessary to maintain the same reproductive performance in

Table III. Performance of multiparous Parda Alpina suckler cows in the Spanish Pyrenees calving in two periods (all cows calved in two successive years).

\begin{tabular}{lcc}
\hline Mean calving date & 29th October & 14th March \\
\hline Age of calves at weaning (months) & 5 & 6 \\
Indoor period & 15th October-15th March & 15th December-15th June \\
Live weight (kg) & & \\
$\quad$ Housing & 635 & 557 \\
$\quad$ Turnout & 570 & 551 \\
Body weight recovery on pasture (kg) & 55.2 & 13.5 \\
Calf weaning weight (kg) & 159 & 186 \\
Annual energy requirements (UFL) & 2610 & 2460 \\
Energy requirements in winter (UFL) & 1490 & 1450 \\
Requirements covered by grazed grass (\%) & 43.5 & 42.1 \\
\hline
\end{tabular}

a Only energy requirements of the dams; calves did not receive any supplement during lactation (Casasus [8]). 
the two calving seasons is similar (table $I I I$ ), and that grazed grass contributes for only $43 \%$ to the total annual energy requirements in both cases. For this reason, autumn calving is being developed in the Spanish Pyrenees, which also provides opportunities for fattening the young calves. These particular management patterns, with short periods of suckling, make good use in summer of pastures with low productivity and mean these cows are in an appropriate physiological condition for maintaining these pastures.

\section{USING SUCKLER COWS TO CONTROL VEGETATION}

Extensification is usually accompanied by simultaneously reduced stocking rate and fertilizer use on grazed pastures [5]. Individual animal performance can sometimes increase, because at least in spring, and so long as the nutritive value of the pasture is maintained, the cows benefit from a high level of feeding owing to the large area of grazing land per cow (large quantities of grass and freedom to select). Young suckled calves and growing cattle, which are more sensitive to pasture quality [19], may, however, suffer later in the grazing season from a fall in the quality of the grass, due to the low spring stocking rate. In this case, supplementation of the calves may be necessary in summer. A lower stocking rate also limits the risk of a grass shortage in years when herbage growth is low. For example, in Auvergne, for an average annual stocking rate of $0.9 \mathrm{LU} \cdot \mathrm{ha}^{-1}$, the variation in the area needed as a consequence of variation in annual grass production is $16 \%$, whereas this variation is $33 \%$ for an average stocking rate of $1.33 \mathrm{LU}^{\mathrm{L}} \mathrm{a}^{-1}$ [22].

However, to maintain the vegetation in a satisfactory state and with a good nutritive value, management has to be adjusted, especially when the stocking rates are greatly reduced. There are several management solutions to this problem, viz., increase the areas mown in spring if the land is acces- sible to machinery, selling animals at the end of spring, etc. One solution, common in countries where ranching is practiced, is to lengthen the grazing period well beyond the period of active vegetation growth. This offers many advantages: reduction in the need for forage harvesting and storage, control of grass growth by early spring grazing and removal of remaining vegetation during the autumn. However, such an extended grazing imposes a period of severe underfeeding on the cows between late autumn and early spring growth. It can be associated with spring calving and a short suckling period. Thus when the cows are dry, they 'clean' the pastures in spring and late autumn; when they are lactating, they have more abundant grass to eat. This possibility has been tested in two contrasting situations; in humid uplands in the Massif Central, and in drier mountain pastures in the Spanish Pyrenees.

In the Massif Central, two durations of grazing season are being compared on two continuously grazed pastures $(1200 \mathrm{~m}$ above sea level) at a low stocking rate (0.6 LU $\cdot \mathrm{ha}^{-1}: 50 \%$ of the potential). The 'control' period lasts 6 months (15 May to 15 November), and the extended period 8.5 months (15 April to the end of December). The cows calve in spring ( 1 st June) and are weaned in mid-October. In April, grazing of the pasture by cows slows the growth of the grass and limits the surplus. In autumn, cows graze the vegetation that was not consumed during summer. The proportion of green plants is higher in the pasture grazed for 8.5 months. Uneaten patches, which are fewer than in the control sward, are, however, not fully harvested in late autumn [10]. There is no difference between the two groups in growth of calves ( $1150 \mathrm{~g} \cdot \mathrm{day}^{-1}$ ). The cows grazing for 8.5 months recover less body condition ( -0.5 units) than those grazing for 6 months. However, the cost of recovering their body reserves, estimated at $100 \mathrm{UFL}$, is less than the saving in conserved feed permitted by prolonging the grazing season (400 UFL). 
In the Spanish Pyrenees, grazing in early winter has been tested with dry or lactating cows with two objectives: i) to minimize winter feed costs; and ii) to clear scrub by grazing. The cows grazed on senescent grass under pine trees after coming down from mountain pastures from October until midJanuary and received an additional straw ration. The spring-calving cows, dried off in October, lost 10 to $15 \mathrm{~kg}$ of live weight on this type of pasture and so were underweight at the following calving in March. Their next calving interval was delayed by 11 days (table IV) compared with other cows fed indoors. Lactating autumn-calving cows lost about $100 \mathrm{~kg}$ when grazing from October to January. Their subsequent calving rate dropped to $40 \%$, while cows fed indoors had a calving rate of $80 \%$ [18]. Under these extreme conditions, the cost in terms of animal performance, of preventing scrub invasion, is very high. Nevertheless, cows with low energy requirements may obtain great benefit from grazing these areas at the beginning of the grass growth period. When these pastures are grazed by dry autumn-calving cows during the spring (April-May), they are able to gain 40 to $50 \mathrm{~kg}$, depending on the previous feeding level [28].
The grazing pressure must be high in some conditions to control certain types of vegetation efficiently. Nardus stricta grows in upland pastures at the expense of other grasses of greater nutritional value to grazing livestock. In one experiment, two grazing pressures were compared with cattle (Common et al., unpublished data). One gave an average grass height between tussocks of Nardus stricta of 6 to $7 \mathrm{~cm}$, the other a height of 4 to $5 \mathrm{~cm}$. In both cases, Nardis stricta regressed, the percentage cover fell by $15 \%$ and by $35 \%$ on the 6 to $7 \mathrm{~cm}$ and 4 to $5 \mathrm{~cm}$ treatments respectively. However, the performance of the animals was low on the high grazing pressure treatment (table $\mathrm{V}$ ), so a lower grazing pressure was recommended, compatible with good animal performance and an efficient control of Nardus stricta. Introduction of other herbivorous species (horses or sheep) with different food preferences [17] can bring about an improvement of these upland pastures [25], and improved performance. In this way, mixed grazing of cattle and sheep, on a Nardus-dominated pasture, for example, results in higher liveweight gain in the sheep compared with sheep grazing alone. The cattle, grazing the Nardus in early summer,

Table IV. Performance of autumn and spring-calving beef cows when indoors or grazing under pine trees in carly winter.

\begin{tabular}{lccccc}
\hline \multirow{2}{*}{$\begin{array}{l}\text { Ealving season } \\
\text { Early winter management }\end{array}$} & Indoors & Outdoors & & \multicolumn{2}{c}{ Spring } \\
\cline { 5 - 6 } Length of outdoor period (days) & 0 & 76 & & Indoors & Outdoors \\
Initial body condition score & 2.6 & 2.6 & & 2.5 & 2.5 \\
Change in score & 0 & -0.5 & & 0 & -0.25 \\
Milk yield (kg) & 6.8 & 3.2 & & 7.2 & 5.8 \\
Calf growth rate (kg/days) & 0.861 & 0.452 & & 0.68 & 0.67 \\
Calving rate (\%) & 80 & 40 & & 78 & 70 \\
Calving interval (days) & 347 & 436 & & 373 & 384 \\
\hline
\end{tabular}

Ferrer et al. [18]. 
Table V. Live weight changes of cows and calves grazing Nardus stricta dominated pasture (grazing pressure was defined as grass height between Nardus stricta tussocks).

\begin{tabular}{lcc}
\hline Grazing pressure & $4-5 \mathrm{~cm}$ & $6-7 \mathrm{~cm}$ \\
\hline Cow liveweight gain (kg/days) & -0.02 & 0.27 \\
Calf liveweight gain (kg/days) & 0.60 & 0.86 \\
\hline
\end{tabular}

Common et al. (unpublished data).

Table VI. Reproductive performance of Salers and Limousin cows in two nutritional environments.

\begin{tabular}{lccccc}
\hline Breed & \multicolumn{2}{c}{ Salers } & & \multicolumn{2}{c}{ Limousin } \\
Nutritional environment & High & Low & & High & Low \\
\hline Calving date & & & & & \\
$\quad$ Primiparous & 19th January & 21 th January & & 2nd February & 26th January \\
$\quad$ Multiparous & 20th January & 27th January & & 1 st February & 3rd February \\
Number of calvings (3-7 years) & 3.38 & 3.39 & & 3.10 & 2.71 \\
Number of calves weaned (3-7 years) & 3.22 & 3.33 & & 2.97 & 2.53 \\
\hline
\end{tabular}

Adapted from D'hour and Petit [12].

improve the nutritive value of the grass regrowth (Howard and Wright, unpublished data).

Where cattle are used to manage vegetation, the reduction in calf weaning weight, or reproductive performance of the cows or the quantities of feed supplements necessary to maintain performance give an estimate of the cost in terms of animal output of maintaining such areas by herds of suckler cows. The management of the herd can, of course, be modified to limit or to alter the type of animal production penalty incurred.

\section{CHOICE OF GENOTYPE}

The characteristics of the animals allow them to adapt to varying degrees to difficult grazing conditions [29]. In particular, in extensive herd management systems, the maternal traits of the cows (ease of calving, maternal behaviour, milk production and regular reproduction) are important. $\mathrm{A}$ high feed intake capacity associated with an ability to mobilize body reserves helps cows to withstand wide variations in feeding levels. Thus several experiments have shown that the performance of suckler herds raised extensively, to varying extents, can be different according to the type or breed of animal. For example, underfed suckler cows with high milk potential maintain their milk production but lose correspondingly more live weight, whereas suckler cows with lower milk potential reduce milk output but lose less live weight $[15,30]$.

The appropriate choice of a genotype adapted to conditions of extensive management is therefore essential, and hardy (often local) breeds are considered to be better adapted to these conditions than specialized breeds. The performance of suckler cows of the Limousin breed (beef type) and Salers breed (dairy type) was compared in two different nutritional environments. One corresponded to intensive management where the cows were permanently well fed. The 
second one mimicked the conditions of extensive feeding management; the cows were underfed during the winter, grazed good pasture from mid-May to mid-August, and then mature grass until late November. These management patterns were applied from weaning ( 9 months) to fourth calving (7 years). The Salers cows had shorter calving intervals than the Limousin cows (table VI) [12]. The Limousin cows had their first calves later, and then reproduced regularly, although more were culled for nonpregnancy, especially among the underfed cows. The number of calvings and the number of calves produced per female from first mating at 2 years was therefore much lower for the underfed Limousin cows (table VI). These results confirm previous observations in more extreme conditions, i.e., outdoor wintering and summer upland grazing at an altitude of $1300 \mathrm{~m} \mathrm{[21]}$; the hardy Salers and Aubrac breeds maintained regular calving intervals better than beef Charolais and Limousin breeds. Calving in the Limousin cows was delayed by 2 weeks and then consistently calved in mid-March, which can be regarded as a form of adaptation.

In France, the Aubrac cows proved to adapt remarkably to extensive management in harsh conditions: Aubrac cows, grazing Molinia pastures under pine trees in the Landes region of SW France, maintained good reproductive performance, unlike beef breeds [20]. Likewise, herds of Aubrac cows were introduced in the Mediterranean region [26] in an area formerly grazed by sheep. These herds are kept outdoors in winter and graze scrubland in spring and summer. Pregnancy rate and weaning rate reach $93 \%$ and $89.2 \%$, respectively (table $V I I$ ), reflecting their ability to be kept on rough vegetation while maintaining a satisfactory level of output. Thus when the primary aim is to maintain the land in an acceptable state, the appropriate choice of breed can keep the cost down.
Table VII. Performances of Aubrac cows in Mediterranean rangeland.

\begin{tabular}{lc}
\hline Number of cows & 1946 \\
\hline Calving date & 25 th February \\
Calving interval (days) & 383 \\
Pregnancy rate (\%) & 93.02 \\
Mortality rate (\%) & 4.85 \\
Calf crop (\%) & 89.2 \\
\hline
\end{tabular}

J. Legendre (unpublished data).

\section{CONCLUSION}

Herd management practices in extensive situations will depend on the relative importance of the roles of the suckler herd, the production of calves or the control of vegetation and maintenance of landscape. The adaptation of different types of cattle to different extensive grazing conditions has to be quantified, together with adjustments to the management system compatible with the land management requirements and the sustainability of the suckler herd. The animal production cost of land maintenance has to be evaluated, and in particular, what level of loss of production is acceptable in the cows. These adjustments to management usually imply calving and the rearing and fattening stages to be dissociated, the cows being managed extensively for land maintenance, while the fattening being carried out more intensively indoors or on more productive pastures.

To exploit marginal and difficult grazing areas, other traits are also required of cattle. In particular, cows have to: i) forage over large expanses of pasture [4]; ii) adapt to different types of vegetation [13]; and iii) remain tractable when handled [23]. It should be noted that cattle may have more difficulty than sheep in coping with shrubby vegetation because of their less selective grazing [17], although small cattle do live on scrubland in, for example, Sardinia and 
Africa. However, cattle can have an important part to play in the maintenance of a range of pasture types, specifically because of their ability to graze coarser more mature grass.

\section{REFERENCES}

[1] Agabricl J., Petit M., Recommandations alimentaires pour les vaches allaitantes, Bull. Tech. C.R.Z.V. Theix, Inra 70 (1987) 153-166.

[2] Agreste, L'Agriculture et l'agroalimentaire dans les régions, ministère de l'Agriculture, France, 1997.

|3| Allen D.M., Liénard G., Suckler Herds in Western Europe, in: Jarrige R. (Ed.), Beef Cattle Production, 1992, 247-258.

[4] Bailey D.W., Dumont B., Wallis De Vrics M.F., Utilization of heterogeneous grasslands by domestic herbivores: theory to management, Ann. Zootech. 47 (1998) 321-333.

[5] Bébin D., Lherm M., Liénard G., L'extensification avec contrat: évolution de quelques exploitations d'élevage bovin Charolais du centre de la France, Fourrages 142 (1995) 107-130.

[6] Bélard J.F., Biannic L., Baud G., Le Maréchal J.Y., Liénard G., Pizaine M.C., Production de jeunes bovins maigres ou engraissés en Limousin, Campagnes 1991/1992, 1992/1993, 1993/1994, Cemagref-Riom, Inra-LEE, Chambre d'agriculture de la Corrèze, 1995

[7] Busselot A., Henriot J., Marsat B., Esteve P., Bouchy R., Fregeac M., Liénard G., Pizaine M.C., Étude technico-économique des systèmes de production en race Salers. Campagnes 1991/ 1992, 1992/1993, 1993/1994, Cemagref-Riom, Inra-LEE, Chambre d'agriculture du Cantal, 1995.

|81 Casasus I., Contribuciòn al estudio de los sistemas de producciòn de ganado vacuno en zonas de montaña: effecto de la raza y de la época de parto sobre la ingestiòn voluntaria de forrajes $y$ los rendimientos en pastoreo, Tesis Doctoral, Universidad de Zaragoza, 1998, $215 \mathrm{p}$.

[9] Casasus I., Ferrer R., Sanz A., Villalba D., Revilla R., Cattle and sheep performances during summer grazing on high mountain ranges in extensive production system, in: proceeding of European workshop on extensification in beef and sheep production, Ghent 14-16 May, 1997.

[10] D’hour P., Josien E., Petit M., Lassalas J., Allongement de la période de pâturage pour les vaches allaitantes, Renc. Rech. Ruminants Paris, 1996, 102.

[11] D'hour P., Petit M., Extensification in suckler herd management, in: proceeding of European workshop on extensification in beef and sheep production, Ghent 14-16 May, 1997.
[12] D'hour P., Petit M., Influence of nutritional environment on reproductive performances of Limousin and Salers cows, in: proceedings 'Suckler cow workers meeting', UK, 15-19 September, 1997.

[13] D'hour P., Petit M., Garel J.P., Components of grazing behaviour of three breeds of heifers, Ann. Zootech. 44 (suppl.) (1995) 270.

[14] D'hour P., Petit M., Garel J.P., Effet de la conduite alimentaire sur le développement et l'âge à la puberté de génisses Limousines et Salers, Renc. Rech. Ruminants 3 (1996) 233-266.

[15] D’hour P., Petit M., Pradel P., Garel J.P., Évolution du poids et de la production laitière au pâturage de vaches allaitantes Salers et Limousines dans deux milieux nutritionnels, Renc. Rech. Ruminants 2 (1995) 105-108.

[16] Daza A., Sistemas de explotaciòn en la España seca, in: Buxadé C. (Ed.), 'Vacuno de carne: aspectos clave', Mundi Prensa, 1997, pp. 191-211.

[17] Dumont B., Diet preferences of herbivores at pasture, Ann. Zootech. 46 (1997) 105-1 16.

[18] Ferrer R., Casasus I., Sanz A., Villalba D., Revilla R., Extensification of beef cattle production systems in the spanish Pyrenees: comparison of performances under indoors vs. grazing conditions, in: proceeding of European workshop on extensification in beef and sheep production, Ghent 14-16 May, 1997.

[19] Ferrer-Cazcarra R., Petit M., D'hour P., The effect of sward height on grazing behaviour and herbage intake of three sizes of Charolais cattle grazing cocksfoot swards, Anim. Sci. 61 (1995) $511-518$.

[20] Grenet N., Liénard G., Malterre C., Entretien d'un troupeau de vaches allaitantes sous couvert forestier dans le Massif Landais, Document interne I.T.E.B., Inra, 1981.

[21] Grenet N., Melet L., Chupin J.M., Le Neindre P., Malterre C., Performances de vaches allaitantes en plein air intégral, in : «Actions du climat sur l'animal au pâturage », Theix, 31 mars-1 $1^{\mathrm{cr}}$ avril 1982, Inra Publications, Versailles, 1982, pp. $31-44$.

[22] Jeannin B., Garel J.P., Beranger C., Micol D., Utilisation de prairies permanentes et temporaires par un troupeau de vaches allaitantes en zone de demi-montagne humide, Fourrages 98 (1984) 19-39

[23] Le Neindre P., Boivin X., Boissy A., Handling of extensively kept animals, Appl. Anim. Behav. Sci. 49 (1996) 73-81.

[24] Liénard G., Lherm M., Bébin D., Les exploitations d'élevage bovin allaitant en zones défavorisćes: évolution, questions, Inra Prod. Anim. 9 (1996) 285-297.

[25] Loiseau P., Martin-Rosset W., Évolution à long terme d'une lande de montagne pâturée par des bovins ou des chevaux, Agronomie 9 (1989) $16 \mathrm{l}-169$. 
[26] Mechain A., Pages L., Legendre J., La reproduction des troupcaux bovins allaitants de race rustiques dans les sytèmes de reconquête territoriale de Languedoc-Roussillon. Renc. Rech. Ruminants 3(1996) 171-174.

[27] Petit M., Garel J.P., D'Hour P., Agabriel J., The use of forages by the beel cow herd, IV Symposium International sur la Nutrition des Herbivores, Clermont-Ferrand. Septembre 1995. Recent Developments in the Nutrition of Herbivores, Inra Editions, Paris, 1995. pp. 473-496.
1281 Revilla R., D’hour P., Thénard V., Petit M., Pâturage des zones de pinedes par des bovins, Renc. Rech. Ruminants 2 (1995) 61-63.

[29| Sinclair K.D., Agabriel J., The adaptation of domestic ruminants to environmental constraints under extensive conditions. Ann. Zootech. 47 (1998) 347-358.

[30] Wright I.A., Russel A.J.F., Hunter E.A., The uses of body condition scoring to ration beef cows in late pregnancy, Anim. Prod. 43 (1986) $391-396$. 